\title{
Relative sheep liveweight gain on perennial lupin, red clover and alsike
}

\begin{abstract}
Young Merino wethers set stocked from November to April, over 5 years, on developed high country legume pastures, at Lake Tekapo at $50 \mathrm{~kg} / \mathrm{ha} / \mathrm{yr}$ superphosphate, showed daily liveweight gain on perennial lupin and alsike clover that were 53\% and 70\%; respectively, of that on Pawera red clover (110 g/day).
\end{abstract}

K eywords: high country, Lupinus polyphyllus, Trifolium hybridum, T. pratense, sheep weight gains

\section{Introduction}

With the increasing agronomic evidence of the potential of the horticultural perennial or Russell lupin (Lupinus polyphyllus Lindley) as a rangeland pasture legume there is a need to determine its effect on animal performance. The agronomic evidence is that perennial lupin produces more dry matter than other legumes, such as alsike (Trifolium hybridum L.) and red clover (T. pratense L.), at lower applied fertiliser rates, on loose-textured moister soils, of the mid to high rainfall areas of the South Island high country (Davis 1981; Scott 1989). Grazing trials have indicated that perennial

- lupin becomes dominant in pasture mixtures at low fertiliser rates, while alsike dominates at moderate fertiliser rates, and white clover ( $T$. repens L.) at high rates with irrigation (Scott 1989, 1993). The same trials have shown that grazing capacity, as determined from the sheep grazing days achieved, was greater from perennial lupin at the low fertiliser rate than from alsike at higher fertiliser rate.

However, field experience is that both perennial lupin and alsike appear less acceptable to sheep in the summer and thus their greater dry-matter production and duration of grazing could be at the expense of lower sheep liveweight gain. This study compares summer sheep liveweight gain on lupin and alsike relative to red clover under conditions of low stocking density, low fertility and set-stocking under which these species might be used in the high country,

\section{$M$ ethods}

The present trial compared 3 species in 2 replicates at the Mt. John trial site, Lake Tekapo on plots sown into

\section{SCOTT, L.A. MAUNSELL and L.M. HUNT AgResearch, PO Box 60, Lincoln, New Zealand}

hieracium-infested fescue tussock, on rolling moraine soils of the Pukaki set. Plots of $50 \times 50 \mathrm{~m}$ were sown using a rotary hoe drill in the spring of 1987 with either Grassland Pawera red clover, commercial alsike clover, or locally collected perennial lupin seed. The drill cultivated and sowed seed in about a third of the area over which it passed, with the potential for resident species to regrow from the remaining area. Additional seed was broadcast onto lupin plots in September 1988. Plots were maintained under a low annual fertiliser rate of $50 \mathrm{~kg} / \mathrm{ha}$ of sulphur fortified superphosphate $(8 \% \mathrm{P}$, 20\%S). After giving the species 2 years to establish, sheep measurements began in 1989 and continued until 1994.

Each year, 1-year-old Merino wethers were set stocked (6-22 sheep/ha; Table 1) on the plots from November to April. At approximately monthly intervals they were weighed after overnight fasting. The stocking rate involved a number of working compromises because of the small total number of sheep that could be run; the need for a similar number of sheep on each plot in all periods; the requirement for an approximate equivalent feed-on-offer per sheep for the different species in the different years; and the need to under-utilise feed in the early summer so that there was sufficient for continuous autumn grazing. In the first two years sheep were re-randomiseddbetween-plots-after-each-monthlyweighing. In the next three years, sheep were confined to particular species treatments, but were re-randomised between replicates after monthly weighings.

Table 1 Mean stocking rate and dry matter feed-on-offer in five measurement years in a comparison of sheep liveweight gain en perennial lupin, red clover and alsike.

\begin{tabular}{cccc}
\hline Attri bute and year & $\begin{array}{c}\text { Perenni al } \\
\text { I upi n }\end{array}$ & $\begin{array}{c}\text { Alsike } \\
\text { cl over }\end{array}$ & $\begin{array}{c}\text { Red } \\
\text { cl over }\end{array}$ \\
\hline Stocki ng rate (sheep/ ha) & & & \\
$89 / 90$ & 6 & 10 & 12 \\
$90 / 91$ & 12 & 12 & 12 \\
91192 & 14 & 12 & 12 \\
$92 / 93$ & 16 & 8 & 12 \\
$93 / 94$ & 22 & 8 & 11 \\
Feed- on- of fer (t DM/ha) & & & \\
$89 / 90$ & $0.5+$ & 0.0 & 1.0 \\
$90 / 91$ & $1.3+$ & 0.9 & 1.1 \\
91192 & $2.0+$ & 1.1 & 1.4 \\
$92 / 93$ & $3.3+$ & 1.7 & 1.7 \\
$93 / 94$ & $3.5+$ & 1.9 & 2.0 \\
\hline
\end{tabular}


Vegetation composition was determined from species rankings prior to stocking each year, and feed-on-offer was determined at monthly intervals by capacitance probe measurements at the same time as the sheep weighings. Because of the sensor height relative to sward height there was underestimation of the perennial lupin feed-on-offer.

\section{Results}

\section{Vegetation}

There was a highly significant difference $(P>0.01)$ in total dry matter feed-on-offer/ha as related to species, year (Table 1), and period within year. The highest mean feed-on-offer was from lupin, which increased over the years, the next highest was from red clover which was relatively stable, and the least from alsike.

There were changes in species dominance in the different treatments. In the third year from when the trial was sown, which was the first sheep measurement year, perennial lupin was still only a minor contributor to its plots, with mouse-ear hawkweed and browntop still dominating. By the last two measurement years the greatest feed-on-offer was from plots dominated by perennial lupin, with mouse-ear hawkweed and fescue tussock being minor contributing species.

By contrast alsike had the highest legume dominance and feed-on-offer in the second establishment year and first measurement year and thereafter declined. By the fifth measurement year, the feed-on-offer in the alsike plots was predominantly browntop and mouse-ear hawkweed.

Red clover maintained its dominance over mouse-ear hawkweed and other resident Species over the trial period and was Second to lupin in feed-on-offer. It had a lesser seasonal decrease because of its greater autumn growth than the other two species.

Total feed-on-offer varied during the season. For each of the 5 months November to March it was 1.9, 2.2, 1.6, 1.2 and $0.7 \mathrm{t} \mathrm{DM/ha}$ on average over the 5 years. There was large variation between feed-on-offer during the January and February period in the different years, as related to climate conditions, particularly rainfall. The data are not presented as they are regarded as experimental variation relative to the more constant seasonal trends and species differences.

\section{Sheep liveweight gain}

The mean sheep liveweight at the start of November grazing period was $29 \mathrm{~kg}$ and increased to $40 \mathrm{~kg}$ at the end of the April period. For each of the 5 months November to March, feed-on-offer per sheep was 206, $250,174,12.5$ and $74 \mathrm{~kg} / \mathrm{sheep}$, on average over the 5 years. Under set stocking these should be less regarded as feed allowance, than the growing base from which forage was continuously harvested.

The variability in the weight gain data was high because of the variability in forage growth between and within years (particularly in the mid summer period), the small number of sheep that could be supported on the plots, and the inherent variability between plots as they represented rangeland conditions. The major trend was for high initial daily sheep growth rates in the late spring, a decrease through the summer and autumn, and a difference between the species in mean growth.

The statistical analysis indicated a highly significant difference between species, years, and period within a year using a conservative ANOVA assuming independence between the measurements, an unbalanced design, but testing for last inclusion in the model. The results and analysis presented (Figure 1) are for the combined measurements for each period for the 5 years as there was no interaction between species and years.

Figure 1 Daily liveweight gain (g/day) of young Merino wethers set stocked on perennial lupin, red clover and alsike. Mean of 5 years. Least significant difference assuming independence of measurement in each period.

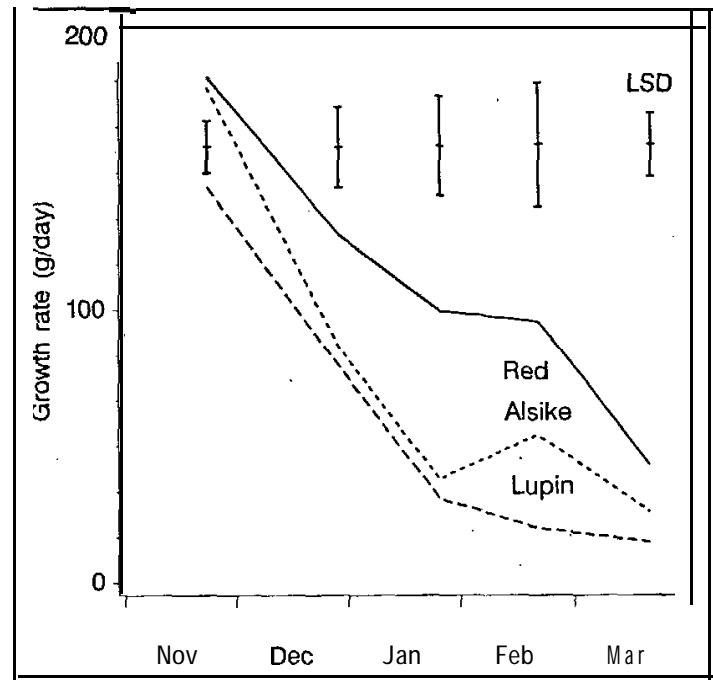

Combining measurements for all monthly periods, the unweighted mean daily weight gains were $58 \mathrm{~g} / \mathrm{day}$ on perennial lupin, $77 \mathrm{~g} /$ day on alsike, and $110 \mathrm{~g} /$ day on red clover $(\mathrm{LSD} 5 \%=10.4 \mathrm{~g} /$ day). The rates on perennial lupin and alsike clover were 53\% and $70 \%$ respectively of those on red clover.

While the species by month interaction was not significant, Figure 1 indicates alsike clover giving a low sheep growth rate similar to that of perennial lupin 
in December and January, but giving increased rates in February.

\section{Discussion}

The results in this trial support the view of superior forage growth and consequent feed-on-offer of perennial lupin on the lower fertility high country soils shown in earlier trials (Davis 1981; Scott 1993).

However, there is a downside of lower unit sheep growth rate, though taken in combination with the higher feed-on-offer, the area carrying capacity is greater once the perennial lupin becomes fully established. Sheep showed high growth rates on all three species in late spring/early summer but liveweight gain decreased thereafter.

The product of mean stocking rate and liveweight gain, shows that red clover produced the highest gain/ha in most years, followed by alsike in the first three years, and surpassed by perennial lupin in the last two years.

Farmer experience has shown alsike is less acceptable to sheep during its major growth of late spring/early summer, but to become acceptable when foliage dries off or is frosted in early autumn. This seems to be reflected in the mean daily weight gains (Figure 1), where gains on alsike relative to the other two species increased (non significant) in late summer.

A further contrast between alsike and perennial lupin is the time scale of their contribution. The measurements covered the third to eighth year of the legume pastures. Alsike, as shown by the stocking rates (Table 1), gave greater carrying capacity in the initial grazing_year_and_thereafter-at-a-reducing-rateBy contrast perennial lupin supported a low stocking rate initially but its capacity increased over the 5-year measurement period.

The change in the legume species dominance over the S-year measurement period is in accordance with experience in other trials as being characteristic of the species, and not related to the differences in grazing pressure on the species in the early measurement years.

While there was no direct measurement of the feeding characteristics of perennial lupin in the present study its characteristics in a lowland-environment have been investigated by Kitessa (Kitessa 1992; Kitessa et al. 1993). In six successive harvests from early foliage growth in October to seed set in January for an established stand, they showed that neutral detergent fibre concentration increased from 24 to $46 \%$, while nitrogen concentration decreased from 4.5 to $2.4 \%$, and in vitro organic matter digestibility decreased from 81 to $55 \%$. In a subsequent study on a newly established lupin stand mob grazed with two-tooth Coopworth ewes at flowering, green pod and dry pod stage, they found no differences in rate of dry matter removal between stages of maturity. Sheep showed an initial preference for leaves, but there was also significant consumption of green and dry pods. Utilisation decreased from $89 \%$ at full flower to $75 \%$ at the dry pod stage. Kitessa (1992) did not determine the relative acceptability to sheep of lupin versus other species, or in vivo digestibility, or sheep weight gains in those trials.

However, the main finding in the present paper is reconfirmation that tetraploid red clovers, like Pawera, are legumes suited to a range of high country environments, and which give high animal performance even when that is not apparent from feed-on-offer. While red clover is normally associated with high fertility moist conditions under hay management, along with timothy and Yorkshire fog, red clover is also among the chief contending pasture species for use in low-fertility droughty conditions. It is also thought of as a short-term species, but as this 8-year trial again shows, Pawera can maintain its dominance at least over this period under set-stocking.

\section{Conclusion}

1. Perennial lupin is a grazing legume suitable for moister, moderate-fertility, high-country sites along with red clover and alsike.

2. While perennial lupin gave the highest amount of feed-on-offer, it gave the lowest per animal weight gain.

3. The per hectare weight gain was highest for red clover,followed by perenniāllupin and àlsike.

\section{REFERENCES}

Davis, M.R. 1981. Growth and nutrition of legumes on a high country yellow brown soil. New Zealand journal of agricultural research 24: 321-337.

Kitessa, S.M. 1992. The nutritional value of Russell lupin (Lupinuspolyphyllus $x \quad L$. arboreus) for sheep. M Agr Sc thesis, Lincoln University, Canterbury, New Zealand.

Kitessa, S.M.; Hill, G.D.; Nicol, A.M. 1993. Yield, composition and in-vitro digestibility of Russell lupin. Proceedings of the XVII International Grasslands Congress: 1801-1802.

Scott, D. 1989. Perennial or Russell lúpin: A potential high country pasture legume. Proceedings of the NZ Grassland Association 50: 203-206.

Scott, D. 1993. Response of Hieracium in two long term manipulative agricultural trials. New Zealand journal of ecology 17: 41-46. 